\title{
Penerapan Model Inquiri pada Pembelajaran Menulis Karangan Eksposisi Siswa Kelas VIII SMP Negeri 1 Sabbang Kabupaten Luwu Utara
}

\author{
Abd. Rahim Ruspa \\ Program Studi Pendidikan Bahasa dan Sastra Indonesia, Universitas Cokroaminoto Palopo \\ rahim.ruspa@gmail.com
}

Abstrak

Penelitian ini bertujuan untuk mendeskripsikan Penerapan Model Inquiri pada Pembelajaran Menulis Karangan Eksposisi Siswa Kelas VIII SMP Negeri 1 Sabbang Kabupaten Luwu Utara Jenis penelitian ini adalah jenis penelitian eksperimen. Pengambilan sampel dalam penelitian ini ditetapkan secara Purposive Sampling yaitu teknik pengambilan sampel sumber data dengan pertimbangan tertentu. Teknik yang digunakan untuk mengumpulkan data dalam penelitian ini yaitu tes awal (pretest) dan tes akhir (posstest). Data yang terkumpul kemudian dianalisis dengan menggunakan teknik analisis statistika deskriptif dan statistika inferensial. Hasil penelitian menunjukkan bahwa hasil belajar siswa kelas VIII 2 SMP Negeri 1 Sabbang sebelum diterapkan model Inquiri berada pada kategori rendah, sedangkan hasil belajar siswa kelas VIII SMP Negeri 1 Sabbang setelah diterapkan model Inquiri berada pada kategori tinggi. Jadi, setelah menerapkan model pembelajaran Inquiri dalam menulis karangan eksposisi siswa kelas VIII 2 SMP Negeri 1 Sabbang efektif digunakan. Hasil SPSS Ver 20 menyimpulkan bahwa $\mathrm{H}_{0}$ ditolak dan $\mathrm{H}_{1}$ diterima artinya ada perbedaan rata-rata nilai sebelum dan sesudah menggunakan model pembelajaran inquiri.

Kata Kunci: Model Inquiri, Karangan Eksposisi

\section{Pendahuluan}

Ahmadi (1998:3) menjelaskan bahwa menulis merupakan suatu sarana dan alat utama untuk penarian dan penemuan (discovery) dan daya tahan kelompok professional, serta juga sebagai aktivitas personal yang mungkin timbul sebagai suatu sarana dan alat ketahanannya di dalam suatu didalam suatu konteks perkembangan ilmu pengetahuan dan ilmu teknologi pengetahuan modern. Salah satu keterampilan menulis menurut Zainurrahman (2013:9) adalah hal yang tidak dapat diperoleh seara alami harus mendapatkan perhatian lebih, karena keterampilan-keterampilan tersebut tidak dapat diperoleh melalui interaksi spontan dan alamiah.

Salah satu aspek keterampilan berbahasa yang berkaitan dengan pengungkapan pikiran, gagasan, pendapat, dan perasaan tersebut adalah keterampilan menulis karangan eksposisi. Keterampilan menulis karangan eksposisi sebagai keterampilan berbahasa yang bersifat produktif-aktif merupakan salah satu kompetensi dasar berbahasa yang harus dimiliki siswa agar terampil berkomunikasi secara tertulis. Hal ini dikarenakan keterampilan menulis bertujuan untuk melatih siswa dalam mengembangkan ide dan menyusunnya menjadi tulisan yang lebih rinci agar mudah dipahami oleh pembaca. Begitu pula dalam menyusun karangan 
eksposisi, pada dasarnya karangan eksposisi merupakan karangan yang disusun untuk memberi pengetahuan maupun informasi kepada orang lain agar bertambah pengetahuannya.

Keterampilan menulis membutuhkan ketekunan dan kreativitas. Siswa dituntut untuk menemukan ide dan merangkai kata untuk menghasilkan tulisan yang baik. Keterampilan menulis merupakan salah satu kemampuan berbahasa dalam mengungkapkan ide, gagasan (pendapat) siswa berupa tulisan. Menulis merupakan bagian yang tidak terpisahkan dalam seluruh proses pembelajaran yang dialami siswa selama menuntut ilmu di sekolah. Menulis memerlukan keterampilan karena diperlukan latihan-latihan yang berkelanjutan dan terus menerus terutama dalam mata pelajaran bahasa Indonesia yang mencakup empat aspek kemampuan berbahasa, yaitu (1) keterampilan menyimak, (2) keterampilan berbicara, (3) keterampilan membaca, dan (4) keterampilan menulis. Menurut Suparno (2008:3) menulis merupakan suatu kegiatan penyampaian pesan (komunikasi) dengan menggunakan bahasa tulis sebagai alat atau medianya.

Keterampilan menulis menurunkan atau melukiskan lambang-lambang grafik yang menggambarkan suatu bahasa yang dipahami oleh seseorang, sehingga orang lain dapat memahami bahasa dan grafik (Tarigan, 2013:22). Dengan menulis orang bisa melakukan komunikasi, mengemukakan gagasan yang baik dari dalam maupun dari luar dirinya dan maupun memperkaya pengalamannya. Menulis merupakan salah satu keterampilan berbahasa yang dibutuhkan untuk meningkatkan kualitas pembelajaran. Dengan penguasaan keterampilan menulis diharapkan siswa dapat mengungkapkan gagasan, pikiran, dan perasaan yang dimilikinya setelah menjalani proses pembelajaran dalam berbagai jenis tulisan, baik fiksi maupun nonfiksi.

Bahasa Indonesia merupakan salah satu materi pelajaran yang sangat penting di sekolah. Tujuan pembelajaran bahasa Indonesia bagi siswa adalah untuk mengembangkan kemampuan berbahasa Indonesia sesuai dengan kemampuan, kebutuhan, dan minatnya. Dalam pembelajaran bahasa Indonesia diperlukan pemberian pemahaman kepada siswa tentang pentingnya belajar bahasa Indonesia dengan mengaitkan materi sesuai dengan kehidupan nyata siswa dan mendorong siswa untuk membuat hubungan antara pengetahuan nyata yang dimiliki dengan penerapannya dalam kehidupan mereka sebagai anggota masyarakat. Menurut (Rusman, 2017:2) kegiatan pembelajaran merupakan upaya untuk menciptakan iklim dan pelayanan terhadap kemampuan, potensi, minat, bakat, dan kebutuhan peserta didik yang beragam agar terjadi interaksi optimal antara guru dan siswa, serta antara siswa dengan siswa.

Menurut Akhadiah (dalam Dalman, 2018:119) karangan eksposisi atau pemaparan adalah suatu corak karangan yang menerangkan atau menginformasikan sesuatu hal yang memperluas pandangan, wawasan atau pengetahuan pembaca. Karangan eksposisi merupakan salah satu jenis karangan yang harus diperkenalkan kepada siswa dan dikuasai oleh seorang guru mata pelajaran bahasa Indonesia. Karangan ini dimaksud untuk memaparkan pengetahuan dan pengalaman si penulis yang diperolehnya dari kajian pustaka atau lapangan dengan tujuan untuk menambah wawasan dan pengetahuan si pembaca tentang suatu hal.

Berbagai permasalahan yang dihadapi sekolah menjadikan pelaku pendidik atau pengajar terus melakukan berbagai perbaikan dalam pembelajaran bahasa Indonesia. Pendidik berupaya untuk terus mencari solusi terhadap masalah-masalah yang timbul dalam pembelajaran tersebut dengan melakukan penelitian terhadap berbagai kompetensi yang berkaitan dengan pembelajaran bahasa Indonesia. Dalam kurikulum 2013 (K13), salah satu kompetensi yang menjadi permasalahan dalam pengajaran bahasa Indonesia yaitu kompetensi keterampilan 
menulis. Adapun target pencapaian kompetensi keterampilan menulis tertuang dalam standar kompetensi menulis siswa kelas VIII SMP pada K13. Dalam hal ini, pencapaian yang dimaksud adalah siswa diharapkan mampu mengungkapkan menyajikan gagasan, pendapat ke dalam bentuk karangan eksposisi dengan menelaah isi dan struktur teks yang kemudian diperdengarkan atau dibaca.

Permasalahan menulis tersebut tidak lepas dari beberapa faktor, yaitu terkait dengan guru, siswa, media, dan model pembelajaran yang digunakan dalam pembelajaran. Untuk mengatasi kesulitan keterampilan menulis karangan eksposisi, salah satu model pembelajaran untuk meningkatkan keterampilan menulis adalah dengan menggunakan model pembelajaran inquiri. Model pembelajaran inquiri dipilih karena model pembelajaran inquiri ini sesuai untuk diterapkan dalam pembelajaran menulis karangan eksposisi. Selain itu, model pembelajaran ini menuntut siswa untuk aktif dalam pembelajaran yang dimana siswa diharapkan langsung bersentuhan dengan objek pelajaran. Dengan model pembelajaran ini, diharapkan siswa mampu menyampaikan informasi ataupun pesan dalam tulisan karangan eksposisi yang mereka susun. Model desain pembelajaran merupakan pengelolaan dan pengembangan yang dilakukan terhadap komponen-komponen pembelajaran. Menurut (Rusman, 2017:262) model inquiri adalah model yang paling sederhana dan sangat mudah untuk diterapkan dalam mengembangkan perencanaan pembelajaran.

Berdasarkan fakta yang diperoleh dari salah satu pengajar, prestasi yang dicapai siswa pada mata pelajaran bahasa Indonesia, khususnya pembelajaran keterampilan menulis karangan eksposisi siswa kelas VIII SMP Negeri 1 Sabbang Kabupaten Luwu Utara masih perlu pembinaan dan pengembangan dalam melatih kecakapan siswa dalam menunangkan ide, gagasan dalam bentuk penulisan karangan eksposisi. Sementara tuntutan kurikulum yang berlaku saat ini, yaitu siswa diharapkan mampu menguasai semua keterampilan berbahasa Indonesia dengan menerapkan standar penilaian rata-rata KKM 75. Oleh karena itu diperlukan model pembelajaran yang kreatif, sederhana dan menyenangkan agar dapat membuat siswa lebih bersemangat dan termotivasi untuk mengikuti pembelajaran. Masalah ini tentu penting untuk diteliti karena hasil observasi yang telah dilakukan di sekolah menunjukkan bahwa salah satu cara yang dapat digunakan untuk merangsang keterampilan siswa dalam menulis karangan eksposisi melalui model inquiri. Model ini diharapkan mampu meningkatkan keterampilan siswa dalam menulis karangan eksposisi.

\section{Metode Penelitian}

Jenis penelitian ini merupakan penelitian eksperimen. Dalam penelitian ini, peneliti mendesain penelitiannya dengan menggunakan desain one group pretest-postest. Ciri dari desain ini adalah adanya pretest sebelum diberi perlakuan dan posttest setelah diberi perlakuan,sehingga hasil perlakuan dapat lebih akurat karena dapat membandingkan dengan kedaan sebelum diberi perlakuan.

Lokasi penelitian ini di SMP Negeri 1 Sabbang. Waktu penelitian dilaksanakan pada semester genap yaitu saat jam pembelajaran bahasa Indonesia berlangsung di kelas VIII.2 SMP Negeri 1 Sabbang. Variabel penelitian terdiri atas dua, yaitu variabel bebas dan variabel terikat. Variabel bebas $(X)$ pada penelitian ini adalah model inquiri, sedangkan variabel terikatnya $(\mathrm{Y})$ adalah pembelajaran menulis karangan eksposisi. Populasi adalah wilayah generalisasi yang terdiri atas objek/subjek yang mempunyai kualitas dan karakteristik tertentu yang ditetapkan oleh peneliti untuk dipelajari dan kemudian ditarik kesimpulannya (Sugiyono, 2011:80). Populasi dalam penelitian ini adalah keseluruhan siswa kelas VIII SMP Negeri 1 
Sabbang Kabupaten Luwu Utara. Teknik pengambilan sampel yang peneliti gunakan, yaitu teknik purposive sampling. Sampel pada penelitian ini adalah siswa kelas VIII 2 SMP Negeri 1 Sabbang Kabupaten Luwu Utara. Peneliti memilih kelas VIII 2 sebagai sampel karena memiliki karakteristik siswa yang heterogen, baik dari tingkat kemampuan siswa, ras, jenis kelamin, dan agama Pertimbangan lainnya adalah keterbatasan waktu penelitian, dana, dan tenaga peneliti.

Teknik yang digunakan untuk pengumpulan data dalam penelitian ini adalah data tes hasil belajar. Adapun langkah-langkah (prosedur) pengumpulan data dalam penelitian ini adalah:

a. Memberikan tes awal (pretest) tentang menulis karangan eksposisi untuk mengukur kemampuan siswa terhadap materi pelajaran sebelum penerapan Model inquiri

b. Memberikan tes akhir (posttest) tentang menulis karangan eksposisi untuk mengukur penguasaan bahan ajar bahasa Indonesia setelah penerapan model inquiri

Data yang telah dikumpulkan dianalisis menggunakan analisis statistika deskriptif dan analisis statistika inferensial. Penelitian ini dianalisis dengan menggunakan program SPSS.

\section{Analisis Statistika Deskriptif}

Analisis deskriptif digunakan untuk menganalisis data hasil belajar. Hasil belajar merupakan bagian terpenting dalam pembelajaran. Hasil belajar dapat dilihat melalui kegiatan evaluasi yang bertujuan untuk mendapatkan data pembuktian yang akan menunjukkan tingkat kemampuan siswa mencapai tujuan pembelajaran.

\section{Analisis Statistika Inferensial}

Statistika inferensial adalah teknik analisis data yang digunakan menganalisis data dan sampel, hasil diberlakukan untuk menguji hipotesis penelitian yaitu uji-t. Sebelum dilakukan pengujian hipotesis, terlebih dahulu dilakukan uji persyaratan yaitu uji normalitas dan one simple $t$-test dari data belajar siswa. Taraf signifikan yang digunakan (a) adalah 0,05 atau 5\%. Adapun analisis yang dilakukan adalah dengan menggunakan SPSS.

a. Uji Normalitas

Uji normalitas digunakan untuk mengetahui apakah data yang diteliti berasal dari populasi berdistribusi normal atau tidak. Adapun pedoman untuk mengambil keputusan dalam uji normalitas yaitu:

1) Jika nilai probabilitas $<0,05$, distribusi adalah tidak normal.

2) Jika nilai probabilitas $\geq 0,05$, distribusi adalah normal.

b. Uji Hipotesis

Untuk menguji hipotesis penelitian digunakan uji-t kriteria pengambilan kesimpulan dalam pengujian statistik, hipotesis ini dinyatakan sebagai berikut.

$\mathrm{H}_{0=} \mathrm{t}_{\text {hitung }} \leq \mathrm{t}_{\text {tabel }}$ lawan: $\mathrm{t}_{\text {hitung }}>\mathrm{n}$

Dengan kriteria pengujian:

$\mathrm{H}_{0}=$ ditolak dan $\mathrm{H}_{1}$ diterima jika nilai $t_{\text {hitung }}<\mathrm{t}_{\text {tabel }}(1-\alpha)$

$\mathrm{H}_{1}$ = diterima dan $\mathrm{H}_{0}$ ditolak jika nilai $\mathrm{t}_{\text {hitung }} \geq \mathrm{t}_{\text {tabel }}(1-\alpha)$

Dengan $\alpha$ adalah taraf kesalahan $5 \%$ : 


\section{Hasil Penelitian}

\section{Skor Hasil Pembelajaran Tes Awal Menulis Karangan Eksposisi}

Data nilai hasil pretest pembelajaran menulis karangan eksposisi sebelum diberi perlakuan. Pembelajaran menulis karangan eksposisi pada tahap ini dilakukan tanpa menggunakan teknik apapun. Hal ini dilakukan dengan tujuan untuk mengetahui kemampuan awal siswa dalam menulis karangan eksposisi. Data pretest dideskripsikan dalam tabel 6 sebagai berikut.

\begin{tabular}{cc} 
Tabel 1. Statistik deskriptif sebelum (pretest) diterapkan model inq \\
\hline Statistik & Nilai statistik \\
\hline Jumlah Sampel & 25 \\
Nilai Rata-rata (Mean) & 62,12 \\
Nilai Tengah (Median) & 60,00 \\
Nilai Tertinggi (Maksimum) & 77,00 \\
Nilai Terendah (Minimum) & 40,00 \\
Standar Deviasi & 10,27 \\
\hline
\end{tabular}

Sumber: data primer setelah diolah (2019)

Tabel 1 menunjukkan bahwa dari 25 sampel, nilai rata-rata yang diperoleh sampel adalah 62,12 dan nilai median yang diperoleh sampel adalah 60,00 Nilai maksimum yang diperoleh sampel adalah 77,00 sedangkan nilai minimum yang diperoleh sampel adalah 40,00 dan standar deviasi 10,27.

Tabel 2. Distribusi frekuensi menulis karangan eksposisi sebelum diterapkan model inquiri

\begin{tabular}{rrrr}
\hline Interval nilai & Kategori & Frekuensi & Persentase (\%) \\
\hline $90-100$ & Sangat tinggi & 0 & 0 \\
$76-85$ & Tinggi & 3 & 12 \\
$70-75$ & Sedang & 6 & 24 \\
$60-65$ & Rendah & 7 & 28 \\
$0-55$ & Sangat rendah & 9 & 36 \\
\hline Total & & 25 & 100 \\
\hline
\end{tabular}

Sumber: Data primer setelah diolah (2019)

Tabel 2 di atas, menunjukkan bahwa nilai pretest siswa dalam menulis karangan eksposisi sebelum menerapkan model inquiri dari 25 sampel dapat dilihat bahwa tidak ada siswa yang mendapat nilai dengan kategori sangat tinggi. Sedangkan 3 orang siswa mendapat nilai kategori tinggi dengan presentase $12 \%, 6$ orang siswa mendapat nilai dengan kategori sedang dengan presentase $24 \%, 7$ orang siswa mendapat nilai dengan kategori rendah dengan presentase $28 \%$, dan 9 orang siswa yang mendapat nilai dengan kategori sangat rendah dengan persentase 36. Dengan demikian, dapat disimpulkan bahwa hasil belajar menulis karangan eksposisi siswa kelas VIII 2 SMP Negeri 1 Sabbang sebelum penerapan model pembelajaran inquiri berada pada kategori sangat rendah.

Tabel 3. Hasil pencapaian KKM prettest

\begin{tabular}{llll}
\hline No & Perolehan Nilai & Frekuensi & Persentase (\%) \\
\hline 1 & Nilai $\geq 75$ & 5 & 20 \\
2 & Nilai $<75$ & 20 & 80 \\
\hline
\end{tabular}

Sumber: Data primer setelah diolah (2019)

Berdasarkan data pada tabel 3 dapat diketahui bahwa hasil pencapaian KKM posttest dalam menulis karangan eksposisi, yang mendapat nilai $\geq 75$ sebanyak 5 orang siswa dengan persentase $20 \%$ sedangkan sdangkan siswa yang mendapat nilai 75 kebawah sebanyak 20 
orang siswa dengan persentase $80 \%$. Dengan demikian, dapat dikatakan bahwa tingkat kemampuan siswa pada pembelajaran menulis karangan eksposisi pretest belum memadai karena, apabila dikonfirmasikan dengan nilai KKM sekolah pada mata pelajaran bahasa Indonesia, yaitu siswa dinyatakan belum meningkat karena jumlah nilai siswa hanya mencapai $20 \%$ yang memperoleh nilai 75 keatas.

\section{Skor Hasil Pembelajaran Posttest (Tes Akhir) Menulis Karangan Eksposisi}

Analisis data posttest dilakukan dengan tujuan untuk mengetahui kemampuan siswa kelas VIII 2 SMP Negeri 1 Sabbang dalam menulis karangan eksposisi setelah penerapan model inquiri. Berikut data posttest dideskripsikan dalam tabel.

Tabel 4. Statistik deskriptif setelah diterapkan model inquiri.

\begin{tabular}{ll}
\hline Statistik & Nilai statistik \\
\hline Jumlah Sampel & 25 \\
Nilai Rata-rata (Mean) & 84,16 \\
Nilai Tengah (Median) & 84,00 \\
Nilai Tertingi (Maksimum) & 97,00 \\
Nilai Terendah (Minimum) & 74,00 \\
Standar Deviasi & 5,42 \\
\hline
\end{tabular}

Sumber: Data primer setelah diolah (2019)

Tabel 4 menunjukkan bahwa tes akhir yang dilakukan 25 sampel, nilai rata-rata yang diperoleh siswa adalah 84,16 , nilai median yang diperoleh siswa adalah 84,00 , nilai maksimum yang diperoleh siswa adalah 97,00 , nilai minimum yang diperoleh siswa adalah 74,00 , dan nilai standar deviasi yang diperoleh siswa adalah 5,42.

Tabel 5. Distribusi frekuensi sebelum diterapkan model pembelajaran inquiri.

\begin{tabular}{llll}
\hline Interval nilai & Kategori & Frekuensi & Persentase (\%) \\
\hline $90-100$ & Sangat tinggi & 6 & 24 \\
$76-85$ & Tinggi & 18 & 72 \\
$70-75$ & Sedang & 1 & 4 \\
$56-65$ & Rendah & 0 & 0 \\
$0-55$ & Sangat rendah & 0 & 0 \\
\hline Total & & 25 & 100 \\
\hline
\end{tabular}

Sumber: Data primer setelah diolah (2019)

Tabel 5 di atas, menunjukkan bahwa dari 25 sampel, nilai sangat tinggi diperoleh 6 orang siswa dengan $24 \%$, nilai tertinggi diperoleh 18 orang siswa dengan $72 \%$, yang memperoleh nilai sedang 1 orang siswa dengan persentase $4 \%$ dan tidak ada siswa yang mendapat nilai dengan kategori sangat rendah. Dengan demikian dapat disimpulkan bahwa hasil belajar menulis karangan eksposisi siswa kelas VIII.2 SMP Negeri 1 Sabbang setelah penerapan model pembelajaran inquiri, berada pada kategori tinggi.

Tabel 6. Hasil pencapaian KKM posttest dalam menulis karangan eksposisi

\begin{tabular}{llll}
\hline No & Perolehan Nilai & Frekuensi & Persentase (\%) \\
\hline 1 & Nilai $\geq 75$ & 24 & 96 \\
2 & Nilai $<75$ & 1 & 4 \\
\hline
\end{tabular}

Sumber: data primer setelah diolah (2019)

Berdasarkan data pada tabel 6 dapat diketahui bahwa hasil pencapaian KKM posttest dalam menulis karangan eksposisi, yang mendapat nilai $\geq 75$ sebanyak 24 orang siswa dengan persentase $96 \%$ sedangkan siswa yang mendapat nilai 75 kebawah sebanyak 1 orang siswa 
dengan persentase $4 \%$. Dengan demikian, dapat dikatakan bahwa tingkat kemampuan siswa pada pembelajaran menulis karangan eksposisi posttest sudah memadai karena, apabila dikonfirmasikan dengan nilai KKM sekolah pada mata pelajaran bahasa Indonesia, yaitu siswa dinyatakan sudah meningkat karena jumlah nilai siswa hanya mencapai $96 \%$ yang memperoleh nilai 75 keatas.

Besarnya peningkatan hasil menulis karangan eksposisi siswa yang diajarkan dengan menggunakan model pembelajaran inquiri. dihitung dengan menngunakan rumus gain ternormalisasi sebagai berikut.

$$
\begin{aligned}
& g=\frac{S_{\text {Post }}-S_{\text {Pre }}}{S_{\text {Max }}-S_{\text {Pre }}} \\
& g=\frac{2104-1553}{2500-1553} \\
& g=\frac{551}{947} \\
& g=0,6
\end{aligned}
$$

Jika peningkatan kemampuan menulis karangan eksposisi siswa dikelompokkan ke dalam klasifikasi gain, maka diperoleh distribusi frekuensi dan persentase.

Tabel 7. Klasifikasi gain ternormalisasi

\begin{tabular}{rrrr}
\hline Koefisien Normalisasi & Klasifikasi & Frekuensi & Persentase (\%) \\
\hline $\mathrm{g}<0,3$ & Rendah & 1 & 4,0 \\
$0,3 \leq \mathrm{g}<0,7$ & Sedang & 20 & 80 \\
$\mathrm{~g} \geq 0,7$ & Tinggi & 4 & 16 \\
\hline Jumlah & & 17 & 100 \\
\hline Rata-rata & 0,6 & & \\
\hline Kategori & Sedang & & \\
\hline
\end{tabular}

Sumber: data primer setelah diolah (2019)

Berdasarkan analisis data, diperoleh keterangan bahwa peningkatan hasil menulis karangan eksposisi siswa kelas VIII 2 SMP Negeri 1 Sabbang setelah diterapkan model pembelajaran inquiri. berada pada kategori sedang dengan rata-rata 0,6.

\section{Hasil Analisis Keaktifan Siswa Dalam Belajar Menulis Karangan Eksposisi}

Aktivitas siswa merupakan keterlibatan siswa selama proses pembelajaran berlangsung mulai dari awal sampai akhir pembelajaran. Data dari lembar observasi, dianalisis berdasarkan kriteria keaktifan siswa selama proses pembelajaran dengan menggunakan model inquiri pada pembelajaran menulis karangan eksposisi yaitu pada pertemuan pertama sampai pertemuan kedua dan diamati oleh seorang observer. Observasi dilaksanakan dengan mengamati setiap aktivitas siswa berdasarkan petunjuk pada lembar aktivitas dengan model inquiri pada setiap pertemuan.

Aspek yang diamati pada setiap pertemuan pada pembelajaran dengan menggunakan model adalah sebagai berikut.

1) Menjawab salam

2) Ketua kelas memimpin siswa berdoa sebelum belajar

3) Mendengarkan dan menjawab ketika namanya disebut 
4) Mendengarkan KD, Indikator, dan Tujuan pembelajaran

5) Mendengarkan dan memahami materi yang akan diberikan oleh guru

6) Pembelajaran dilakukan dengan cara melihat langsung atau menggunakan objek sesuai dengan mata pelajaran dan tujuan pembelajaran. Jadi seorang siswa diharapkan langsung bersentuhan dengan objek pelajaran. Dalam hal ini siswa lebih ditekankan pada praktik

7) Menetapkan pengalaman belajar berupa penetapan bahan atau materi apa yang akan disampaikan guru, kemudian guru mengarahkan siswa untuk terjun langsung ke lapangan

8) Menetapkan prosedur pembelajaran yang sesuai dengan tujuan pembelajaran dan materi yang akan disampaikan kepada siswa, sehingga sesuai prosedurnya.

9) Pembelajaran diharapkan dapat mengubah penampilan atau perilaku siswa secara tetap atau perilaku siswa yang menetap

10) Penyimpulan

11) Evaluasi

12) Penutup

Tabel 8. Aktivitas Siswa

\begin{tabular}{|c|c|c|c|c|}
\hline \multirow{2}{*}{$\begin{array}{l}\text { Aspek yang } \\
\text { dinilai }\end{array}$} & \multicolumn{2}{|c|}{ Pertemuan } & \multirow{2}{*}{ Jumlah } & \multirow[t]{2}{*}{ Rata-rate } \\
\hline & 1 & 2 & & \\
\hline 1 & 4 & 4 & 8 & 4 \\
\hline 2 & 4 & 4 & 8 & 4 \\
\hline 3 & 4 & 4 & 8 & 4 \\
\hline 4 & 3 & 3 & 6 & 3 \\
\hline 5 & 3 & 3 & 6 & 3 \\
\hline 6 & 3 & 3 & 6 & 3 \\
\hline 7 & 3 & 4 & 7 & 3.5 \\
\hline 8 & 3 & 3 & 6 & 3 \\
\hline 9 & 4 & 4 & 8 & 4 \\
\hline 10 & 4 & 4 & 8 & 4 \\
\hline 11 & 4 & 3 & 7 & 3.5 \\
\hline 12 & 3 & 3 & 6 & 3 \\
\hline Jumlah & 42 & 42 & 84 & 42 \\
\hline \multicolumn{3}{|l|}{ Rata-rata aktiv } & 1,7 & \\
\hline
\end{tabular}

Sumber: Data primer setelah diolah (2019)

Berdasarkan tabel 8 rata-rata aktivitas siswa dengan menggunakan model inquiri maka hasilnya perolehan skor untuk rata-rata keseluruhan aktivitas siswa dari pertemuan pertama hingga kedua sebesar 1,7 . 


\section{Hasil Analisis Data Respons Siswa kelas VIII 2 SMP Negeri 1 Sabbang}

Data hasil respons siswa terhadap pembelajaran menulis karangan eksposisi setelah menggunakan model inquiri diperoleh dari angket yang dibagikan kepada siswa setelah proses pembelajaran selesai. Adapun yang dinilai pada angket respons siswa adalah sebagai berikut.

1) Model inquiri adalah hal yang baru bagi saya

2) Pembelajaran bahasa Indonesia yang dilaksanakan dengan menggunakan model inquiri mendorong saya belajar bahasa Indonesia lebih baik dari biasanya.

3) Kegiatan pembelajaran bahasa Indonesia yang telah dilaksanakan membantu saya lebih mudah memahami pelajaran bahasa Indonesia dengan model inquiri pada materi menulis karangan eksposisi

4) Pembelajaran bahasa Indonesia dengan model inquiri pada menulis karangan eksposisi perlu terus diterapkan karena menuntut siswa lebih aktif dalam penyerapan pengetahuannya dari pada guru yang hanya menjelaskan materi dan siswa hanya mendengarkan.

5) Pembelajaran yang dilaksanakan dengan menggunakan model inquiri pada pembelajaran menulis karangan eksposisi sangat menarik.

6) Pembelajaran yang dilaksanakan dengan menggunakan model inquiri pada menulis karangan eksposisi membuat saya semangat belajar.

7) Pembelajaran bahasa Indonesia dengan menggunakan model inquiri perlu diterapkan dalam pembelajaran bahasa Indonesia dengan materi yang lain selain menulis karangan eksposisi

8) Saya lebih banyak menyerap pembelajaran bahasa Indonesia pada menulis karangan eksposisi dengan menggunakan model inquiri

9) Saya cukup puas dan bangga dengan pengalaman belajar atau pencapaian hasil belajar selama mengikuti proses pembelajaran bahasa Indonesia melalui model inquiri

Bobot pernyataan angka respons siswa adalah skor untuk respons dengan sangat setuju (SS), 4 untuk setuju (ST), 3 untuk tidak setuju (TS), 2 dan 1 untuk sangat tidak setuju (STS).

Rata-rata respons siswa ditunjukkan pada tabel dibawah ini.

Tabel 9. Deskripsi nilai rata-rata respons siswa dengan menggunakan model inquiri

\begin{tabular}{lll}
\hline No Pertanyaan & Jumlah & Rata-rata \\
\hline 1 & 85 & 3.4 \\
2 & 86 & 3.4 \\
3 & 84 & 3.4 \\
4 & 82 & 3.3 \\
5 & 86 & 3.4 \\
6 & 91 & 3.6 \\
7 & 88 & 3.5 \\
8 & 86 & 3.4 \\
9 & 84 & 3.4 \\
\hline Jumlah & 772 & 30,9 \\
\hline Rata-rata & \multirow{2}{*}{3.4} & \\
keseluruhan & & \\
\hline
\end{tabular}

Sumber: Data primer setelah diolah (2019) 
Berdasarkan tabel 9 menunjukkan bahwa perolehan skor rata-rata untuk respons siswa dengan menggunakan model inquiri dalah 3,4.

\section{Pembahasan}

Berdasarkan analisis statistika deskriptif menjukkan bahwa hasil belajar siswa kelas VIII SMP Negeri 1 Sabbang pada pembelajaran menulis karangan eksposisi sebelum diterapkan model inquiri dikategorikan sangat rendah dengan frekuensi 9 dan persentase $36 \%$. Hasil analisis statistika deskriptif yang menunjukkan siswa kelas VIII SMP Negeri 1 Sabbang pada pembelajaran menulis karangan eksposisi setelah diterapkan model inquiri dikategorikan tinggi dengan frekuensi 18 dan persentase $72 \%$.

Siswa yang mencapai nilai kriteria ketuntasan klasikal (KKM) 75 ke bawah pada pretest adalah 20 orang siswa dengan persentase $80 \%$ dan siswa yang mencapai 75 keatas adalah 5 orang siswa dengan persentase $20 \%$, sedangkan pada posttest siswa yang mencapai 75 keatas adalah 24 orang siswa dengan persentase $96 \%$ dan 75 ke bawah adalah 1 orang siswa dengan persentase 4\%. Berdasarkan nilai pretest dan posttest dapat dilihat bahwa hasil belajar siswa kelas VIII 2 SMP Negeri 1 Sabbang efektif. Hal ini disebabkan karena minat belajar siswa yang di dukung oleh bakat dan kemampuan yang dimiliki serta bimbingan belajar baik secara individu maupun bimbingan kelompok, sehingga dapat menguasai sepenuhnya materi atau mencapai ketuntasan belajar.

Hasil analisis aktivitas siswa pada pembelajaran menulis karangan eksposisi siswa kelas VIII SMP Negeri 1 Sabbang diperoleh nilai rata-rata keseluruhan yaitu 1,7. Data respons siswa berfungsi untuk mengetahui pendapat siswa dalam pembelajaran menulis karangan eksposisi setelah diterapkan model inquiri sesuai indikator yang ada pada angket respons siswa. Sembilan pernyataan yang telah dipaparkan menunjukkan nilai rata-rata keseluruhan respons siswa yaitu 2,0. Jadi, dapat disimpulkan bahwa penerapan model inquiri pada pembelajaran menulis karangan eksposisi sisiwa efektif digunakan.

\section{Kesimpulan}

Berdasarkan hasil penelitian yang dilakukan, dapat disimpulkan bahwa hasil menulis karangan eksposisi siswa kelas VIII 2 SMP Negeri 1 Sabbang sebelum diterapkan model pembelajaran inquiri berada pada kategori rendah. Dan Hasil menulis karangan eksposisi siswa kelas VIII 2 SMP Negeri 1 Sabbang setelah diterapkan model pembelajaran inquiri berada pada kategori tinggi. Siswa yang mencapai KKM 75 ke atas (tuntas) pada posttest adalah 24 orang siswa dengan persentase $96 \%$ dan siswa yang mencapai 75 ke bawah adalah 1 orang siswa dengan persentase $4 \%$. Jadi dapat disimpulkan bahwa model inquiri efektif diterapkan pada pembelajaran menulis karangan eksposisi siswa kelas VIII 2 SMP Negeri 1 Sabbang. Hasil SPSS Ver 20 menyimpulkan bahwa $\mathrm{H}_{0}$ ditolak dan $\mathrm{H}_{1}$ diterima artinya ada perbedaan rata-rata nilai sebelum dan sesudah menggunakan model pembelajaran inquiri.

\section{Referensi}

Ayungtias, E. S. (2017). Penerapan Model Pembelajaran Inquiri di Tinjau dari Pemahaman Siswa pada Pokok Bahasan Fungsi Kelas VII SMP Negeri 3 Kota Kediri tahun ajaran 2016/2017. Skripsi tidak diterbitkan. Kediri. Universitas Nusantara PGRI Kediri.

Dalman. (2018). Keterampilan Menulis. Depok: PT Raja Grafindo Persada.

Djumingin, S. (2011). Strategi dan Aplikasi Model Pembelajaran Inovatif Bahasa Indonesia. Makassar: Universitas Negeri Makassar. 
Vol. 2, No. 3, September - December 2019

ISSN 2654-6477

Nurgiyantoro, B. (2014). Penilaian Pembelajaran Berbasis Komputer. Yogyakarta: BPFE.

Rusman. (2017). Model-model Pembelajaran Berorientasi Standar Proses Pendidikan. Jakarta: Kencana.

Sugiyono. (2011). Metode Penelitian Kuantitatif, Kualitatif dan R\&D. Bandung: Alfabeta. Tarigan, H. G. (2013). Menulis. Bandung: Angkasa.

Zainurrahman. (2013). Menulis: Dari Teori Hingga Praktik. Bandung: Alfabeta. 